\title{
Properties and characterization of biodegradable films obtained from different starch sources
}

\author{
Antonio Augusto Marques RODRIGUES ${ }^{1,2}$, Rayssa Ribeiro da COSTA ${ }^{1}$, Luana Ferreira dos SANTOS ${ }^{1}$, \\ Silvanda de Melo SILVA ${ }^{1}$, Douglas de BRITTO ${ }^{3}$, Maria Auxiliadora Coêlho de LIMA ${ }^{3 *}$ (D)
}

\begin{abstract}
The increasing use of natural biodegradable polymers to preserve foods is a consequence of the concern of society with sustainability. Starch stands out amongst the natural polymers due to its great availability on a worldwide scale, high extraction yield and nutritional value, low cost, biodegradability and biocompatibility. Apart from the traditional sources, various others exist with extraction potential. The objective of this study was to identify films from different non-traditional starch sources with properties revealing their potential to be applied as coating for fruits and vegetables. The biodegradable films were prepared with three starch concentrations (2, 3 and 3.5\%) for each of the following sources: cassava, yam, jackfruit seed and mango kernel. The starches from the sources studied are promising ingredients for the formulation of films, presenting good physical, optical (such as transparency) and mechanical characteristics, principally tensile strength whose maximum value was 36.63 MPa. Increases in starch concentration directly influenced the thickness, water vapor permeability, tensile strength and puncture force. The films with the greatest potentials for use according to their characteristics were $3 \%$ cassava, $3 \%$ yam, 3.5\% jackfruit seed and 2\% mango.
\end{abstract}

Keywords: water vapor permeability; mechanical properties; optical properties.

Practical Application: Films from starch sources with appropriate characteristics to apply to fresh products.

\section{Introduction}

Most polymers used to manufacture packaging materials are petroleum-based and are therefore not biodegradable, causing a great impact on the environment when discarded (Arfat et al., 2017). This reality encourages the use of natural biodegradable polymers for food packaging (Priyadarshi et al., 2018).

The development of edible and/or biodegradable films is an alternative for the total or partial substitution of synthetic polymers in the manufacture of packaging, a use which is coherent with concerns for environmental conservation and a healthier life style (Dick et al., 2015). The polymers from renewable sources most used to form films are polysaccharides and proteins (Fernandes et al., 2020; Han, 2014), and of the polysaccharides starch stands out for its film-forming properties, great availability, high extraction yield and nutritional value, low cost, biodegradability, biocompatibility and for being edible (Shah et al., 2016).

The starch must be heated to form a filmogenic solution, since starch granules are not soluble in cold water, even though they absorb a certain amount of cold water and swell. With the increase in temperature, so the starch granules vibrate intensely, breaking intermolecular bonds, establishing hydrogen bonds with the water, and causing a decrease in the number and size of crystalline regions. Thus, the viscosity of the solution increases considerably, since, due to swelling, the granules stick to one another and, with agitation, acquire a gelatinous aspect (Corke et al., 2016).

Various sources are available for starch extraction, corn, wheat, rice and potato being the most common (Bagheri et al., 201; Caballero et al., 2015; Ee et al., 2020; Santoso et al., 2019). Apart from these sources, one could mention cassava (Manihot esculenta Crantz), which has great dietary importance, mainly in Africa and South America, as well as various other non-traditional sources with the potential for extraction and use as biodegradable films or coverings, due to their high yield, starch content and good chemical composition. Since they show these characteristics, yam (Dioscorea spp.), jackfruit (Artocarpus heterophyllus Lam.) seeds and mango (Mangifera indica L.) kernels are considered potential sources of this polysaccharide (Falade \& Ayetigbo, 2015; Guimarães et al., 2017; Madruga et al., 2014; Torres-León et al., 2018).

Nevertheless, the highly hydrophilic character makes the starch films a poor water vapor barrier. Besides, starch undergoes a process of retrogradation, implying in variations of its mechanical properties with time (Li et al., 2015). The addition of a plasticizing agent such as glycerol can avoid such problem (Gutiérrez et al., 2015). 
The ideal characteristics of a food packaging film include reduced moisture transference, good mechanical resistance, proper elasticity, transparency and avoiding interference with the appearance of the product (Gutiérrez et al., 2015). The study of the barrier properties and of the optical and mechanical characteristics of the films formed as from non-traditional starch sources in different concentrations, will support the identification of materials for the development of new biodegradable structures. Also, the need to include any additives to improve the adhesion and stability of the matrix will be identified.

The objective of this study was to identify films made from different non-traditional starch sources with properties revealing their potential to be applied as coating for fruits and vegetables.

\section{Materials and methods}

The starches were extracted from cassava, yam (Dioscorea cayennensis Lam.), mango kernel and jackfruit seed. The cassava and yam were obtained in the local market, in Petrolina-PE, Brazil. The mango kernels were donated by the fruit pulp company Valle Fruit and the jackfruit seeds were collected in a rural zone in the municipality of Areia-PB, Brazil. To obtain the starches, the raw materials were peeled, washed under running water and immersed in a $50 \mathrm{ppm}$ sodium hypochlorite solution for $10 \mathrm{~min}$. They were then finely grounded in an industrial blender. The grounded mass was suspended in water and filtered through a cotton cloth. The starch was separated from the water suspension by decantation ( 12 hours) at ambient temperature $\left(25^{\circ} \mathrm{C} \pm 2{ }^{\circ} \mathrm{C}\right)$. The suspension was centrifuged twice at $1100 \mathrm{rpm}$ for $5 \mathrm{~min}$ at $25^{\circ} \mathrm{C}$. The starch was purified by freeze-drying for 24 hours.

The biodegradable starch films were prepared in three concentrations: 2,3 and $3.5 \% \mathrm{v} / \mathrm{w}$. To prepare the filmogenic solutions, the cassava starch was heated to $70^{\circ} \mathrm{C}$ (Azerêdo et al., 2016), the jackfruit seed and mango kernel starches to $85^{\circ} \mathrm{C}$ (Bharti et al., 2019; Madruga et al., 2014) and the yam starch to $90{ }^{\circ} \mathrm{C}$ (Gutiérrez et al., 2015), all for 15 minutes with constant magnetic stirring. Following, glycerol was added at a concentration of $1 \%$, as proposed by Rodrigues et al. (2018), and the suspension was homogenized at $10,000 \mathrm{rpm}$ for 5 minutes. The films were formed on $25 \mathrm{x} 15 \mathrm{~cm}$ Teflon plates and allowed to dry by casting for $48 \mathrm{~h}$ at $24^{\circ} \mathrm{C}$ and $50 \% \mathrm{RH}$.

The films were characterized with respect to: thickness, water solubility, water vapor permeability, color, transparency, tensile strength, elasticity and puncture force.

The thicknesses of the films were determined using a micrometer (Mitutoyo, Model MDC-25M, MFG, Japan), reporting the mean values in $\mu \mathrm{m}$ of five measurements taken at random.

The water solubility was determined as the percent of the film dry matter soluble in water according to Hafsa et al. (2016). Samples of $2 \mathrm{~cm}^{2}$ of known moisture content were weighed, placed in $50 \mathrm{~mL}$ of distilled water and shaken for 24 hours at $25^{\circ} \mathrm{C}$. The film was then removed and the samples dried in an oven at $105^{\circ} \mathrm{C}$ to constant weight. The percent solubility was calculated using the following Equation 1:

Water solubility $(\%)=\frac{\text { initial mass }- \text { final mass }}{\text { initial mass }} \times 100$
The water vapor permeability (WVP) was determined according to ASTM E96-00 (American Society for Testing and Materials, 2000) with some modifications. The films, in the form of disks, were placed in a cell containing water on the inside, the position of the membrane guaranteeing that any loss of water occurred exclusively by passing through the film. The cells were placed in a desiccator in a conditioned air room with controlled relative humidity and weighed every 24 hours for 7 consecutive days using an analytical balance. The analyses were carried out with 4 repetitions for each type of film. The permeability was calculated in $\mathrm{kg} \mathrm{mm} \mathrm{Pa}^{-1} \mathrm{~h}^{-1} \mathrm{~m}^{-2}$ using the following Equation 2:

$\mathrm{WVP}=\frac{\text { rate of loss } \mathrm{x} \text { thickness }}{\text { saturation pressure } \mathrm{x} \text { area }}$

The color characterization was carried out using a colorimeter (Konica Minolta, CR 400, Japan) with the CIELAB system represented by: L (luminosity), chromaticity $\mathrm{a}^{*}$ (-a green, $+\mathrm{a}$ red) and chromaticity $b^{*}(-b$ blue,$+b$ yellow). Five readings were taken for each film, determining the total color difference $(\Delta \mathrm{E})$ using the means of the standards $\mathrm{L}, \mathrm{a}^{*}$ and $\mathrm{b}^{*}$ in the Equation 3:

$\Delta \mathrm{E}=\left[\left(\mathrm{L}-\mathrm{L}_{0}\right)^{2}+\left(\mathrm{a} *-\mathrm{a}_{0}\right)^{2}+\left(\mathrm{b}^{*}-\mathrm{b}_{0}\right)^{2}\right]^{0.5}$

Where the values for $L, a^{\star}$ and $b^{*}$ were the measurements taken for the films and $\mathrm{L}_{0}, \mathrm{a}_{0}$ and $\mathrm{b}_{0}$ correspond to the white standard $\left(\mathrm{L}_{0}=94.38 ; \mathrm{a}_{0}{ }^{*}=-0.71 ; \mathrm{b}_{0}{ }^{*}=3.9\right)$ (Goyeneche et al., 2014; Pires et al., 2013).

Film transparency was determined in a UV-Vis spectrophotometer (Varian, model Carry 50 Bio, UV-Vis, Mulgrave VIC, Australia). The film samples were fixed in the cuvette such that the light beam passed through the film. The transparency was determined at 600 nm in triplicate (Han \& Floros, 1997) and the values, expressed in percentage, calculated from the following Equation 4:

$\operatorname{Transparency}(\%)=\frac{\operatorname{Abs}(600 \mathrm{~nm})}{\text { Thickness }}$

The mechanical properties were determined by tensile tests (tensile strength and elasticity) using a DL (Digital Line) universal test machine (EMIC). The measurements were carried out according to the standard method of the American Society for Tests and Materials D882-97 (American Society for Testing and Materials, 1997). The specimen used was $25 \mathrm{~mm}$ wide and $115 \mathrm{~mm}$ long, the space between the claws was adjusted to $60 \mathrm{~mm}$, the velocity was $1.0 \mathrm{~mm} \mathrm{~s}^{-1}$ and five repetitions were made.

The puncture force was determined using an electronic texturometer (Extralab TAXT Plus, Stable Micro Systems, Surrey, United Kingdom), the films being fixed to two acrylic plates where the diameter of the opening was $60 \mathrm{~mm}$, and perforated with a $6 \mathrm{~mm}$ diameter tip, moving perpendicularly at a velocity of $1 \mathrm{~mm} \mathrm{~s}^{-1}$ according to Gontard et al. (1994).

The data were submitted to an analysis of variance and the mean values compared using Tukey's test ( $\mathrm{p} \leq 0.05)$. The principal components analysis was used to correlate the variables that most differed between the films, Jolliffe's criterion (Jolliffe, 1972) to establish the importance of the variables in each component and the cluster analysis to group the more similar films according 
to the variables. The analyses were carried out using the JMP 10.0.0 software.

\section{Results and discussion}

The film thicknesses varied from 54 to $92 \mu \mathrm{m}$, the thickest ones being those made with 3.5\% yam or mango kernel starches (Table 1). In general, the higher the starch concentration, the thicker the film, independent of the starch source, increasing by almost $50 \%$ when the concentration increased from 2 to $3.5 \%$. A similar response tendency was mentioned by Santoso et al (2019) evaluating corn starch-based edible film added with gambier (Uncaria gambir) powder filtrate. Wang et al. (2017), studying starch extracted from normal, waxy and high amylose content corns, also reported an increase in film thickness as the carbohydrate concentration increased. The increase in thickness is due mainly to the larger amount of mass which, with a greater number of granules, gives a larger surface area, improving the interaction with the plasticizer.

Thickness is an important characteristic of films since it is linked to the barrier properties such as WVP and permeability to $\mathrm{O}_{2}$ and $\mathrm{CO}_{2}$. Since starch-based films are hydrophilic, the thickness may particularly influence the WVP, due to the difference between the water vapor pressure and the moisture accumulation at the film interface (Gutiérrez et al., 2015).

Water solubility varied from 11.56 to $24.96 \%$, the highest values being found for all concentrations of cassava starch and the $2 \%$ jackfruit seed starch (Table 1 ). These values were smaller or similar to those reported in the literature. Silva et al. (2019) reported values of $10-23 \%$ for cassava-based films and Moosavian \& Mohammadi Nafchi (2017) found values of 22 to $32 \%$ for cassavabased films containing mint. On the other hand, Luchese et al. (2018) reported solubilities of from 13.7 to $26.5 \%$ for films based on potato, wheat, cassava and corn. However, there is no ideal value for solubility, since it depends on the application or way in which the film will be used (Pelissari et al., 2013). For example, films used to protect foods with high water activity and those used to avoid exudation from fresh or frozen products, have distinct solubilities. Studying the addition of green banana biomass in a processed food, Pivetta et al. (2020) concluded that it provided an increase in moisture and water activity due to its water retention capacity related to the high content of resistant starch.

The start of dissolution can be explained by the fact that the solvent molecules, on being absorbed by the polymers, penetrate the macromolecular network, forcing the polymeric chains to separate. This loosening of the polymer structure occurs due to the liberation of components from the matrix to the environment after a certain exposure period (Priyadarshi et al., 2018).

The WVP was greater for the mango kernel and yam starches, differing from the other sources (Table 1). In general, the starch concentration did not influence the WVP and it should be noted that films from the sources presenting the thickest films (mango kernel and yam) also showed the highest WVP. Gutiérrez et al. (2015) pointed out that thicker films increased the resistance to water transfer and the partial pressure at equilibrium of the water at the internal surface of the films.

This is the most important property of biodegradable films due to its relationship with deteriorative reactions, affecting the shelf life of the product. From this property one can estimate how much water will be lost or gained from foods covered with this film, since the higher the WVP the easier it is for water molecules to diffuse in the polysaccharide network (Dick et al., 2015).

The values observed in this study are lower than those reported by other authors (Gutiérrez et al., 2015; Dick et al., 2015). However, several factors, including the source of hydrocolloid

Table 1. Physical and optical characteristics of the films based on different concentrations of cassava (CS), jackfruit seed (JS), mango kernel (MKS) and yam (YS) starches*.

\begin{tabular}{|c|c|c|c|c|c|c|c|c|}
\hline Film & $\begin{array}{c}\text { Thickness } \\
(\mu \mathrm{m})\end{array}$ & $\begin{array}{c}\text { Water } \\
\text { solubility }(\%)\end{array}$ & $\begin{array}{c}\text { Water vapor } \\
\text { permeability } \\
\left(\mathrm{Kg} \mathrm{mm} \mathrm{Pa}^{-1} \mathrm{~h}^{-1} \mathrm{~m}^{-2}\right)\end{array}$ & $\mathbf{L}$ & $a^{*}$ & $\mathbf{b}^{*}$ & $\begin{array}{l}\text { Total color } \\
\text { difference } \\
(\Delta E)\end{array}$ & $\begin{array}{c}\text { Transparency } \\
(\%)\end{array}$ \\
\hline CS $2 \%$ & $54^{\mathrm{f}}$ & $26.38^{a}$ & $3.45 \times 10^{-10 b c}$ & $93.87^{\mathrm{a}}$ & $-0.51^{\mathrm{cd}}$ & $4.09^{\mathrm{ef}}$ & $0.20^{c}$ & $3.35^{\mathrm{f}}$ \\
\hline CS $3 \%$ & $70^{\mathrm{de}}$ & $24.03^{\mathrm{abc}}$ & $3.19 \times 10^{-10 b c}$ & $93.46^{\mathrm{ab}}$ & $-0.62^{\mathrm{fg}}$ & $4.29^{\mathrm{def}}$ & $0.56^{c}$ & $2.74^{\mathrm{h}}$ \\
\hline CS $3.5 \%$ & $74^{\mathrm{cd}}$ & $24.96^{\mathrm{ab}}$ & $3.14 \times 10^{-10 b c}$ & $93.61^{\mathrm{ab}}$ & $-0.60^{\text {efg }}$ & $4.13^{\mathrm{def}}$ & $0.34^{\mathrm{c}}$ & $2.14^{j}$ \\
\hline JS 2\% & $60^{\mathrm{ef}}$ & $24.85^{\mathrm{ab}}$ & $3.03 \times 10^{-10 c}$ & $93.76^{\mathrm{ab}}$ & $-0.55^{\text {def }}$ & $4.44^{\text {cde }}$ & $0.38^{c}$ & $3.57^{\mathrm{e}}$ \\
\hline JS $3 \%$ & $76^{\mathrm{bcd}}$ & $18.38 \mathrm{~b}^{\mathrm{cd}}$ & $3.21 \times 10^{-10 b c}$ & $93.30^{\mathrm{b}}$ & $-0.61^{\mathrm{fg}}$ & $4.78^{c}$ & $0.98^{c}$ & $2.29^{\mathrm{i}}$ \\
\hline JS 3.5\% & $89^{\mathrm{ab}}$ & $16.76^{\mathrm{cd}}$ & $4.39 \times 10^{-10 b}$ & $93.81^{\mathrm{a}}$ & $-0.52^{\mathrm{de}}$ & $4.57^{\mathrm{cd}}$ & $0.45^{c}$ & $1.62^{\mathrm{k}}$ \\
\hline MKS 2\% & $71^{\mathrm{de}}$ & $12.48^{\mathrm{d}}$ & $16.4 \times 10^{-10 a}$ & $91.94^{c}$ & $-0.65^{g}$ & $8.17^{b}$ & $12.08^{b}$ & $7.35^{c}$ \\
\hline MKS 3\% & $87^{\mathrm{abc}}$ & $16.54^{\mathrm{d}}$ & $14.4 \times 10^{-10 \mathrm{a}}$ & $91.76^{c}$ & $-1.21^{\mathrm{h}}$ & $10.28^{\mathrm{a}}$ & $24.11^{\mathrm{a}}$ & $8.94^{\mathrm{a}}$ \\
\hline MKS 3.5\% & $90^{\mathrm{a}}$ & $15.99^{\mathrm{d}}$ & $15.8 \times 10^{-10 \mathrm{a}}$ & $91.74^{\mathrm{c}}$ & $-1.32^{\mathrm{i}}$ & $10.52^{\mathrm{a}}$ & $25.68^{a}$ & $7.62^{\mathrm{b}}$ \\
\hline YS 2\% & $64^{\mathrm{def}}$ & $18.61^{\mathrm{bcd}}$ & $11.3 \times 10^{-10 \mathrm{a}}$ & $93.67^{\mathrm{ab}}$ & $-0.33^{a}$ & $3.98^{\mathrm{ef}}$ & $0.34^{\mathrm{c}}$ & $6.03^{\mathrm{d}}$ \\
\hline YS 3\% & $85^{\mathrm{abc}}$ & $12.37^{\mathrm{d}}$ & $15.6 \times 10^{-10 a}$ & $93.88^{\mathrm{a}}$ & $-0.41^{\mathrm{ab}}$ & $3.92^{\mathrm{f}}$ & $0.18^{c}$ & $3.00^{\mathrm{g}}$ \\
\hline YS $3.5 \%$ & $92^{\mathrm{a}}$ & $11.56^{\mathrm{d}}$ & $13.2 \times 10^{-10 \mathrm{a}}$ & $93.74^{\mathrm{ab}}$ & $-0.44^{b c}$ & $3.94^{\mathrm{f}}$ & $0.25^{\mathrm{c}}$ & $2.14^{\mathrm{j}}$ \\
\hline
\end{tabular}

${ }^{*}$ Means followed by the same lowercase letter in the column do not differ from each other using Tukeys's test $(\mathrm{p} \leq 0.05)$. 
and its proportion, the reduced thickness, the difference in the proportion of the plasticizer and the differences in the test procedure, can affect WVP. Furthermore, Fernandes et al. (2020) reported that the addition of oligosaccharides, as xylooligosaccharide and galactooligosaccharide, decreased WVP, measured in a whey protein-based film. This effect is usually verified for films added with hydrophobic compounds, like lipids and waxes.

Compounds, as catechins and glycerol, containing high numbers of hydroxyl $(\mathrm{OH})$ groups cause edible film to have hydrophilic property which in turn affect the increase of water vapor transmission rate of edible film. Also, increase of free space amongst polymers and increase of polymers mobility are a consequence of high numbers of OH (Santoso et al., 2019).

The color of biodegradable films is important for consumer acceptance. According to the values found for luminosity $(\mathrm{L}), \mathrm{a}^{*}$, $\mathrm{b}^{*}$, the color difference $(\Delta \mathrm{E})$ and transparency $(\mathrm{T})$, the mango kernel starch films, independent of their concentration, present a yellower color than the other films, characterized by a lower value for $\mathrm{L}$, higher value for $\mathrm{b}^{*}$, higher $\Delta \mathrm{E}$ and greater value for $\mathrm{T}$ (Table 1). For the last variable, the higher the value the more opaque was the film.

The differences in color can be attributed to small amounts of other materials in the starch, such as proteins, fibers, sugars, latex, pigments, lipids and minerals, which are not removed during the extraction. These other constituents can also cause chemical changes in the starch, making film formation difficult (Falade \& Ayetigbo, 2015; Pelissari et al., 2013).

According to Priyadarshi et al. (2018), transparency is another important property of films for food packaging since consumers want the product to be visible. In the present study the transparency varied from 1.62 (highly transparent) to 8.94 . These values are close to those reported by Ramos et al. (2013), who observed values of $3.05,1.67$ and 1.51, respectively, for low density polyethylene (LDPE) films, oriented polypropylene (OPP) and polyethylene.

The mechanical properties are important characteristics in the packaging development process, since the material must show resistance to mechanical stress, maintaining its integrity during transport, handling and storage (Priyadarshi et al., 2018). Table 2 shows the mechanical characteristics of tensile strength (TS), elasticity (E) and puncture force (PF).

The tensile strength measures the deformation of the sample when a force is applied at a constant rate. The greatest tensile strength was found for the 3.5\% yam starch, with a mean value of $36.63 \mathrm{MPa}$ (Table 2). This greater value obtained for the yam starch could be related to its amylose content, since amylose has more stable bonds and hence the potential to form stronger films (López \& García, 2012). In general, the tensile strength increased with the starch concentration in the present study.

The mean values observed, from 6.64 to $36.63 \mathrm{MPa}$, are within the ranges reported by other authors for starch-based films. López \& García (2012) mentioned values of $31.8 \mathrm{MPa}$ for corn starch, 36.7 MPa for jacatupe (Pachyrhizus ahipa (Wedd.)
Table 2. Mechanical properties of tensile strength, elasticity and puncture force of films based on cassava (CS), jackfruit seed (JS), mango kernel (MKS) and yam (YS) starches*.

\begin{tabular}{cccc}
\hline Film & $\begin{array}{c}\text { Tensile strength } \\
(\mathbf{M P a})\end{array}$ & Elasticity (\%) & $\begin{array}{c}\text { Puncture force } \\
(\mathbf{N})\end{array}$ \\
\hline CS 2\% & $11.19^{\mathrm{d}}$ & $5.01^{\mathrm{c}}$ & $5.40^{\mathrm{f}}$ \\
CS 3\% & $24.30^{\mathrm{c}}$ & $5.09^{\mathrm{c}}$ & $10.90^{\mathrm{de}}$ \\
CS 3.5\% & $28.15^{\mathrm{abc}}$ & $6.62^{\mathrm{c}}$ & $15.65^{\mathrm{ab}}$ \\
JS 2\% & $6.64^{\mathrm{d}}$ & $26.79^{\mathrm{a}}$ & $8.76^{\mathrm{e}}$ \\
JS 3\% & $24.20^{\mathrm{c}}$ & $5.73^{\mathrm{c}}$ & $15.58^{\mathrm{ab}}$ \\
JS 3.5\% & $33.83^{\mathrm{ab}}$ & $6.61^{\mathrm{c}}$ & $17.67^{\mathrm{a}}$ \\
MKS 2\% & $10.54^{\mathrm{d}}$ & $16.26^{\mathrm{b}}$ & $3.73^{\mathrm{f}}$ \\
MKS 3\% & $23.50^{\mathrm{c}}$ & $5.22^{\mathrm{c}}$ & $8.92^{\mathrm{e}}$ \\
MKS 3.5\% & $33.02^{\mathrm{ab}}$ & $7.76^{\mathrm{c}}$ & $14.52^{\mathrm{bc}}$ \\
YS 2\% & $22.08^{\mathrm{c}}$ & $9.50^{\mathrm{bc}}$ & $9.72^{\mathrm{e}}$ \\
YS 3\% & $26.83^{\mathrm{bc}}$ & $6.39^{\mathrm{c}}$ & $13.18^{\mathrm{cd}}$ \\
YS 3.5\% & $36.63^{\mathrm{a}}$ & $10.74^{\mathrm{bc}}$ & $17.03^{\mathrm{a}}$ \\
\hline
\end{tabular}

${ }^{*}$ Means followed by the same lowercase letter in the column do not differ from each other using Tukeys's test $(\mathrm{p} \leq 0.05)$.

Parodi) starch and 29.7 MPa for cassava starch. Ortega-Toro et al. (2014) reported values of $8.4-24.3 \mathrm{MPa}$ for corn starch with different glycerol concentrations, and Pelissari et al. (2013) observed values of 19.3 MPa for banana starch. Compared to synthetic films, this range is within the values reported by Chambi \& Grosso (2011) who reported values of 23 to 28 MPa for low density polyethylene, whereas Polat et al. (2018), studying metallic nano particles, mentioned tensile strength values between 15.36 and $18.99 \mathrm{MPa}$. The values found for the biodegradable films were close to those of the synthetic films, showing the potential of starch for this end, presenting the necessary resistance for handling of the packaging without predisposing the food product to damage.

Besides, additives can improve mechanical properties of films. An example is the addition of prebiotic components. According to Fernandes et al. (2020), at concentrations greater than $20 \%$ to the films, these components led to a significant decrease in tensile strength and an increase in elongation to break and thickness values.

The elasticity increased from the original length of the sample to the breaking point, with practically no difference between the films, except for the $2 \%$ jackfruit seed starch, which presented $26.79 \%$ (Table 2). As the films became more elastic, their resistance to traction decreased and, consequently, their integrity decreased. Thus, the best choice for films would be those presenting moderate elasticity.

Pivetta et al. (2020) mentioned that higher percentage of starch result in lower elasticity. Specifically, amylose content in starch granules has a significant impact on the physicochemical, thermal and rheological properties (Ee et al., 2020). In addition, Santoso et al. (2019) emphasized that the trapped hydroxyl (OH) 
Table 3. Autovectors of the two principal components (PC1, PC2) for the variables analyzed in the biodegradable films based on cassava, jackfruit seed, mango kernel and yam starches*.

\begin{tabular}{lcc}
\hline \multirow{2}{*}{ Variable } & \multicolumn{2}{c}{ Autovector } \\
\cline { 2 - 3 } & PC1 & PC2 \\
\hline Tensile strength & 0.079 & $\mathbf{0 . 5 3 5}$ \\
Elasticity & -0.044 & -0.298 \\
Puncture force & -0.056 & $\mathbf{0 . 5 1 2}$ \\
Thickness & 0.229 & $\mathbf{0 . 4 5 2}$ \\
Lightness & $\mathbf{- 0 . 4 0 4}$ & 0.118 \\
${ }^{* a}$ & $\mathbf{- 0 . 3 6 6}$ & 0.029 \\
${ }^{\star b}$ & $\mathbf{0 . 4 1 3}$ & -0.094 \\
Total color difference $(\Delta \mathrm{E})$ & $\mathbf{0 . 4 1 5}$ & -0.066 \\
Water vapor permeability $(\mathrm{WVP})$ & $\mathbf{0 . 3 2 6}$ & 0.066 \\
Water solubility & -0.231 & -0.263 \\
Transparency & $\mathbf{0 . 3 6 7}$ & -0.238 \\
Eigenvalue & 5.445 & 3.166 \\
Accumulated variability $(\%)$ & 49.49 & 78.27 \\
\hline
\end{tabular}

*The values of the autovectors in bold indicate those important to explain the differences between the treatments.

groups can result in cohesive power decrease of edible film matrix which in turn affect the elasticity of edible film.

According to Table 2 the most resistant films as evaluated by the perforation force were $3.5 \%$ cassava starch $(15.65 \mathrm{~N}), 3$ and $3.5 \%$ jackfruit seed starch $(15.58$ and $17.67 \mathrm{~N})$ and $3.5 \%$ yam starch $(17.03 \mathrm{~N})$. In general, an increase in starch concentration resulted in a greater force to perforate the film, independent of the starch source, the values showing the same behavior as tensile stress. All the 3 and 3.5\% starch concentration films showed higher values than those reported by other authors. Araujo-Farro et al. (2010) reported 7.1 $\mathrm{N}$ for quinoa starch, while Andrade-Mahecha (2009) reported $8 \mathrm{~N}$ for arrowroot starch and Pelissari et al. (2013) $6 \mathrm{~N}$ for banana starch. Moreover, a study about amylose cross-linked variants from rice starch in processed food showed a softer texture compared to the use of the native starch (Bagheri et al., 2018).

Both the transparency and the mechanical properties of the films from the four starch sources are similar to those reported for commercial films derived from petroleum, indicating their potential use. Of the differences between the films based on cassava starch, jackfruit seed starch, mango kernel starch and yam starch with respect to the variables analyzed, $78.27 \%$ were explained by two of the principal components (Table 3). For component 1 , the variables presenting the greatest importance to explain the differences between the films were $L, a^{*}, b^{*}$, $\Delta \mathrm{E}, \mathrm{WVP}$ and transparency (T). For component 2 the most important variables were TS, PF and thickness. Thus, the variables that did not present relevance to explain the differences between the biodegradable films were the elasticity (E) and solubility, since these presented low autovectors for all the principal components.

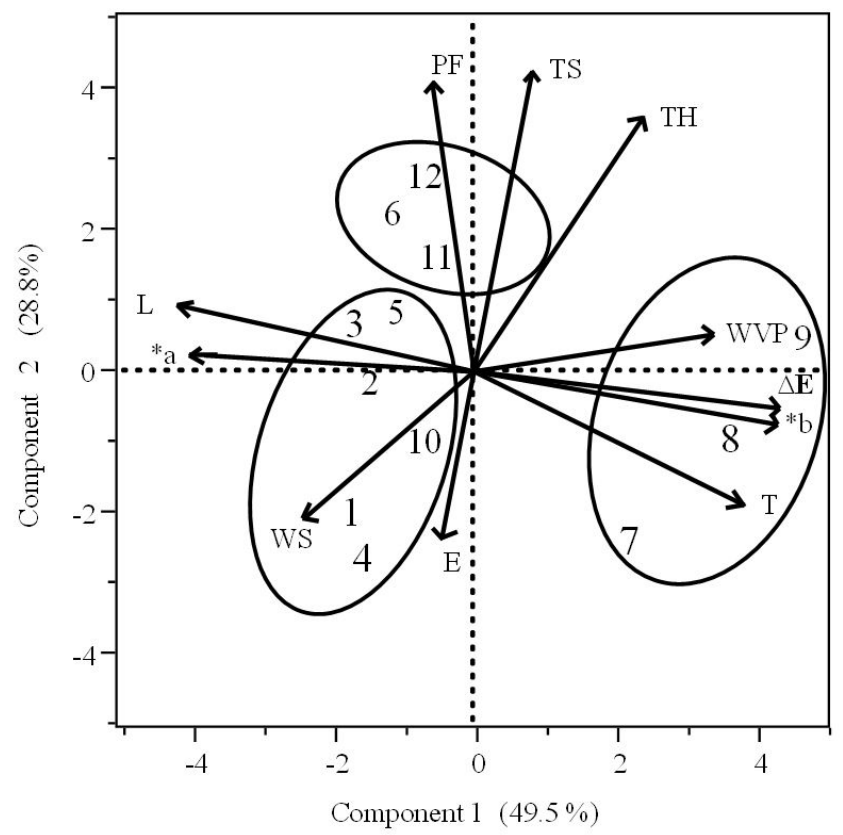

Figure 1. Autovectors assembled into three groups according to the variables analyzed in the biodegradable films based on cassava, jackfruit seed, mango kernel and yam starches. $1=2 \%$ cassava starch; $2=3 \%$ cassava starch; $3=3.5 \%$ cassava starch; $4=2 \%$ jackfruit seed starch; $5=3 \%$ jackfruit seed starch; $6=3.5 \%$ jackfruit seed starch; $7=2 \%$ mango kernel starch; $8=3 \%$ mango kernel starch; $9=3.5 \%$ mango kernel starch; $10=2 \%$ yam starch; $11=3 \%$ yam starch; $12=3.5 \%$ yam starch. $\mathrm{TS}=$ tensile strength, $\mathrm{E}=$ elasticity, $\mathrm{PF}=$ puncture force, $\mathrm{Th}=$ thickness, $\mathrm{L}=$ lightness, $\Delta \mathrm{E}=$ total color difference, $\mathrm{WVP}=$ water vapor permeability, $\mathrm{WS}=$ water solubility, $\mathrm{T}=$ transparency.

As from the similarities between the biodegradable films, the cluster analysis separated them into 3 groups (Figure 1). In the first group the films $2 \%$ CS, $3 \%$ CS, $3.5 \%$ CS, $2 \%$ JS and $2 \%$ YS were separated from the others since they presented greater luminosity, higher values for the color component $\mathrm{a}^{\star}$ and greater solubility. In group 2 the films 3.5\% JS, 3\% YS and 3.5\% YS were associated since they presented greater values for the perforation force, greater tensile strength and were thicker. Group 3 consisted of films made from all concentrations of mango kernel starch since they presented greater water vapor permeability, a greater color difference in relation to the standard $(\Delta \mathrm{E})$, higher values for the color component $\mathrm{b}^{*}$ and greater transparency values, indicating less transparent films.

\section{Conclusions}

The non-traditional jackfruit seed, mango kernel and yam starches were shown to be of promise for film formulation similar to cassava, presenting good physical, optical and mechanical characteristics. The starch concentration used affected the film characteristics, greater concentrations increasing the thickness, water vapor permeability, tensile stress and puncture force. Considering all the characteristics studied, the films with greatest potential for each starch source were 3\% cassava starch, 3.5\% jackfruit seed starch, 2\% mango starch and 3\% yam starch. 


\section{Acknowledgements}

The authors would like to acknowledge CAPES - Coordenação de Aperfeiçoamento de Pessoal de Nível Superior, for providing the D.Sc. fellowship for the first author; Univasf - Universidade Federal do Vale do São Francisco for allowing the use of some equipments; and the company Valle Fruit for donating the raw material of mango starch.

\section{References}

American Society for Testing and Materials - ASTM. (1997). Annual book of ASTM standards (D882-97: standard test method for tensile properties of thin plastic sheeting, pp. 159-197). Philadelphia: ASTM.

American Society for Testing and Materials - ASTM. (2000). Annual book of ASTM standards (E96-00: standard method for water vapor transmission of materials, pp. 785-792). Philadelphia: ASTM.

Andrade-Mahecha, M. M. (2009). Elaboração e caracterização de biofilmes de farinha de biri (Canna indica L.). (Dissertação de mestrado). Universidade Estadual de Campinas, Campinas.

Araujo-Farro, P. C., Podadera, G., Sobral, P. J., \& Menegalli, F. C. (2010). Development of films based on quinoa (Chenopodium quinoa, Willdenow) starch. Carbohydrate Polymers, 81(4), 839-848. http://dx.doi.org/10.1016/j.carbpol.2010.03.051.

Arfat, Y. A., Ejaz, M., Jacob, H., \& Ahmed, J. (2017). Deciphering the potential of guar gum/Ag-Cu nanocomposite films as an active food packaging material. Carbohydrate Polymers, 157, 65-71. http://dx.doi.org/10.1016/j.carbpol.2016.09.069. PMid:27987974.

Azerêdo, L. P. M., Silva, S. D. M., Lima, M. A. C., Dantas, R. L., \& Pereira, W. E. (2016). Quality of 'Tommy Atkins' mango from integrated production coated with cassava starch associated with essential oils and chitosan. Revista Brasileira de Fruticultura, 38(1), 141-150. http://dx.doi.org/10.1590/0100-2945-270/14.

Bagheri, F., Radi, M., \& Amiri, S. (2018). Evaluating the function of cross-linked rice starch as a fat replacer in low fat cream. International Journal of Dairy Technology, 71(4), 981-991. http://dx.doi.org/10.1111/1471-0307.12510.

Bharti, I., Singh, S., \& Saxena, D. C. (2019). Influence of alkali treatment on physicochemical, pasting, morphological and structural properties of mango kernel starches derived from Indian cultivars. International Journal of Biological Macromolecules, 125, 203-212. http://dx.doi.org/10.1016/j.ijbiomac.2018.12.034. PMid:30521921.

Caballero, B., Finglas, P., \& Toldrá, F. (2015). Encyclopedia of food and health. Cambridge: Academic Press.

Chambi, H. N. M., \& Grosso, C. R. F. (2011). Mechanical and water vapor permeability properties of biodegradables films based on methylcellulose, glucomannan, pectin and gelatin. Food Science and Technology (Campinas), 31(3), 739-746. http://dx.doi.org/10.1590/ S0101-20612011000300029.

Corke, H., Faubion, J., Seetheraman, K., \& Wrigley, C. (2016). Encyclopedia of food grains. Cambridge: Academic Press.

Dick, M., Costa, T. M., Gomaa, A., Subirade, M., Rios, Ade. O., \& Flôres, S. H. (2015). Edible film production from chia seed mucilage: effect of glycerol concentration on its physicochemical and mechanical properties. Carbohydrate Polymers, 130, 198-205. http://dx.doi.org/10.1016/j.carbpol.2015.05.040. PMid:26076617.

Ee, K. Y., Eng, M. K., \& Lee, M. L. (2020). Physicochemical, thermal and rheological properties of commercial wheat flours and corresponding starches. Food Science and Technology (Campinas), 40(Suppl. 1), 51-59. http://dx.doi.org/10.1590/fst.39718.
Falade, K. O., \& Ayetigbo, O. E. (2015). Effects of annealing, acid hydrolysis and citric acid modifications on physical and functional properties of starches from four yam (Dioscorea spp.) cultivars. Food Hydrocolloids, 43, 529-539. http://dx.doi.org/10.1016/j. foodhyd.2014.07.008.

Fernandes, L. M., Guimarães, J. T., Silva, R., Rocha, R. S., Coutinho, N. M., Balthazar, C. F., Calvalcanti, R. N., Piler, C. W., Pimentel, T. C., Neto, R. P. C., Tavares, M. I. B., Esmerino, E. A., Freitas, M. Q., Silva, M. C., \& Cruz, A. G. (2020). Whey protein films added with galactooligosaccharide and xylooligosaccharide. Food Hydrocolloids, 104, 105755. http://dx.doi.org/10.1016/j. foodhyd.2020.105755.

Gontard, N., Duchez, C., Cuq, J.-L., \& Guilbert, S. (1994). Edible composite films of wheat gluten and lipids: water vapour permeability and other physical properties. International Journal of Food Science \& Technology, 29(1), 39-50. http://dx.doi. org/10.1111/j.1365-2621.1994.tb02045.x.

Goyeneche, R., Agüero, M. V., Roura, S., \& Di Scala, K. (2014). Application of citric acid and mild heat shock to minimally processed sliced radish: color evaluation. Postharvest Biology and Technology, 93, 106-113. http://dx.doi.org/10.1016/j. postharvbio.2014.02.011.

Guimarães, G. H. C., Dantas, R. L., de Sousa, A. S. B., Soares, L. G., Melo, R. S. R., Silva, R., \& Silva, S.M. (2017). Impact of cassava starch-alginate based coatings added with ascorbic acid and elicitor on quality and sensory attributes during pineapple storage. African Journal of Agricultural Research, 12(9), 664-673. http://dx.doi.org/10.5897/AJAR2016.11652.

Gutiérrez, T. J., Tapia, M. S., Pérez, E., \& Famá, L. (2015). Structural and mechanical properties of edible films made from native and modified cush-cush yam and cassava starch. Food Hydrocolloids, 45, 211-217. http://dx.doi.org/10.1016/j.foodhyd.2014.11.017.

Hafsa, J., Smach, M., Ben Khedher, M. R., Charfeddine, B., Limem, K., Majdoub, H., \& Rouatbi, S. (2016). Physical, antioxidant and antimicrobial properties of chitosan films containing Eucalyptus globulus essential oil. Lebensmittel-Wissenschaft + Technologie, 68, 356-364. http://dx.doi.org/10.1016/j.lwt.2015.12.050.

Han, J. H. (2014). Innovations in food packaging. Cambridge: Academic Press.

Han, J. H., \& Floros, J. D. (1997). Casting antimicrobial packaging films and measuring their physical properties and antimicrobial activity. Journal of Plastic Film \& Sheeting, 13(4), 287-298. http://dx.doi.org/10.1177/875608799701300405.

Jolliffe, I. T. (1972). I. Artificial data. Applied Statistics, 21(2), 160-173. http://dx.doi.org/10.2307/2346488.

Li, J., Ye, F., Liu, J., \& Zhao, G. (2015). Effects of octenylsuccination on physical, mechanical and moisture-proof properties of stretchable sweet potato starch film. Food Hydrocolloids, 46, 226-232. http://dx.doi.org/10.1016/j.foodhyd.2014.12.017.

López, O. V., \& García, M. A. (2012). Starch films from a novel (Pachyrhizus ahipa) and conventional sources: development and characterization. Materials Science and Engineering C, 32(7), 19311940. http://dx.doi.org/10.1016/j.msec.2012.05.035.

Luchese, C. L., Benelli, P., Spada, J. C., \& Tessaro, I. C. (2018). Impact of the starch source on the physicochemical properties and biodegradability of different starch-based films. Journal of Applied Polymer Science, 135(33), 46564. http://dx.doi.org/10.1002/app.46564.

Madruga, M. S., de Albuquerque, F. S., Silva, I. R., do Amaral, D. S., Magnani, M., \& Queiroga, V. No. (2014). Chemical, morphological and functional properties of Brazilian jackfruit (Artocarpus 
heterophyllus L.) seeds starch. Food Chemistry, 143, 440-445. http://dx.doi.org/10.1016/j.foodchem.2013.08.003. PMid:24054264.

Moosavian, V., \& Mohammadi Nafchi, A. (2017). Biodegradable films based on cassava starch/mentha piperita essence: fabrication, characterization and properties. Journal of Chemical Health Risks, 7, 3. http://dx.doi.org/10.22034/JCHR.2017.544185.

Ortega-Toro, R., Jiménez, A., Talens, P., \& Chiralt, A. (2014). Effect of the incorporation of surfactants on the physical properties of corn starch films. Food Hydrocolloids, 38, 66-75. http://dx.doi. org/10.1016/j.foodhyd.2013.11.011.

Pelissari, F. M., Andrade-Mahecha, M. M., Sobral, P. J. A., \& Menegalli, F. C. (2013). Comparative study on the properties of flour and starch films of plantain bananas (Musa paradisiaca). Food Hydrocolloids, 30(2), 681-690. http://dx.doi.org/10.1016/j.foodhyd.2012.08.007.

Pires, C., Ramos, C., Teixeira, B., Batista, I., Nunes, L., \& Marques, A. (2013). Hake proteins edible films incorporated with essential oils: physical, mechanical, antioxidant and antibacterial properties. Food Hydrocolloids, 30(1), 224-231. http://dx.doi.org/10.1016/j. foodhyd.2012.05.019.

Pivetta, F. P., Silva, M. N., Tagliapietra, B. L., \& Richards, N. S. S. (2020). Addition of green banana biomass as partial substitute for fat and encapsulated Lactobacillus acidophilus in requeijão cremoso processed cheese. Food Science and Technology, 40(2), 451-457. https://doi.org/10.1590/fst.03919.

Polat, S., Fenercioğlu, H., \& Güçlü, M. (2018). Effects of metal nanoparticles on the physical and migration properties of low density polyethylene films. Journal of Food Engineering, 229, 32-42. http://dx.doi.org/10.1016/j.jfoodeng.2017.12.004.

Priyadarshi, R., Sauraj, Kumar, B., \& Negi, Y. S. (2018). Chitosan film incorporated with citric acid and glycerol as an active packaging material for extension of green chilli shelf life. Carbohydrate Polymers, 195, 329338. http://dx.doi.org/10.1016/j.carbpol.2018.04.089. PMid:29804984.

Ramos, Ó. L., Reinas, I., Silva, S. I., Fernandes, J. C., Cerqueira, M. A., Pereira, R. N., Vicente, A. A., Poças, M. F., Pintado, M. E., \& Malcata,
F. X. (2013). Effect of whey protein purity and glycerol content upon physical properties of edible films manufactured therefrom. Food Hydrocolloids, 30(1), 110-122. http://dx.doi.org/10.1016/j. foodhyd.2012.05.001.

Rodrigues, A. A. M., Silva, S. de M., Dantas, A. L., Silva, A. F. D., Santos, L. D. S., \& Moreira, D. D. N. (2018). Physiology and postharvest conservation of 'Paluma' guava under coatings using Jack fruit seed-based starch. Revista Brasileira de Fruticultura, 40(2). http://dx.doi.org/10.1590/0100-29452018352.

Santoso, B., Hazirah, R., Priyanto, G., Hermanto, \& Sugito, (2019). Utilization of Uncaria gambir Roxb filtrate in the formation of bioactive edible films based on corn starch. Food Science and Technology (Campinas), 39(4), 837-842. http://dx.doi.org/10.1590/fst.06318.

Shah, U., Naqash, F., Gani, A., \& Masoodi, F. A. (2016). Art and science behind modified starch edible films and coatings: a review. Comprehensive Reviews in Food Science and Food Safety, 15(3), 568580. http://dx.doi.org/10.1111/1541-4337.12197.

Silva, O. A., Pellá, M. G., Pellá, M. G., Caetano, J., Simões, M. R., Bittencourt, P. R. S., \& Dragunski, D. C. (2019). Synthesis and characterization of a low solubility edible film based on native cassava starch. International Journal of Biological Macromolecules, 128, 290-296. http://dx.doi.org/10.1016/j.ijbiomac.2019.01.132. PMid:30685306.

Torres-León, C., Vicente, A. A., Flores-López, M. L., Rojas, R., SernaCock, L., Alvarez-Pérez, O. B., \& Aguilar, C. N. (2018). Edible films and coatings based on mango (var. Ataulfo) by-products to improve gas transfer rate of peach. Lebensmittel-Wissenschaft + Technologie, 97, 624-631. http://dx.doi.org/10.1016/j.lwt.2018.07.057.

Wang, K., Wang, W., Ye, R., Liu, A., Xiao, J., Liu, Y., \& Zhao, Y. (2017). Mechanical properties and solubility in water of corn starch-collagen composite films: Effect of starch type and concentrations. Food Chemistry, 216, 209-216. http://dx.doi.org/10.1016/j.foodchem.2016.08.048. PMid:27596411. 